Review

\title{
Cancer-Associated Fibroblasts in Undifferentiated Nasopharyngeal Carcinoma: A Putative Role for the EBV-Encoded Oncoprotein, LMP1
}

\author{
Mhairi A. Morris (D) \\ School of Sport, Exercise and Health Sciences, Loughborough University, Loughborough LE11 3TU, UK; \\ M.A.Morris@lboro.ac.uk
}

Received: 29 November 2019; Accepted: 18 December 2019; Published: 20 December 2019

\begin{abstract}
Undifferentiated nasopharyngeal carcinoma (NPC) is 100\% associated with Epstein-Barr virus (EBV) infection, and biopsies display variable levels of expression of the viral oncoprotein, latent membrane protein 1 (LMP1). Emerging evidence suggests an important role for cancer-associated fibroblasts (CAFs) in the NPC tumour microenvironment, yet the interaction between the virus, its latent gene products and the recruitment and activation of CAFs in the NPC tumour stroma remains unclear. This short review will discuss the current evidence for the importance of CAFs in NPC pathogenesis and outline a putative role for the EBV-encoded oncoprotein, LMP1, in governing tumour-stromal interactions.
\end{abstract}

Keywords: EBV; LMP1; NPC; fibroblast; myofibroblast; cancer-associated fibroblasts; tumour microenvironment; tumour stroma

\section{Introduction}

Undifferentiated nasopharyngeal carcinoma (NPC) is a relatively rare type of head and neck cancer on a global scale, with an incidence of 1.2 cases per 100,000 people, worldwide. However, it exhibits unusually high incidence rates in parts of Southeast Asia, with between 15 and 50 cases per 100,000 in the population [1]. There are numerous causal factors for NPC, including dietary preferences, environmental risk factors and hereditary genetic predispositions, but uniquely, undifferentiated NPC is 100\% associated with Epstein-Barr virus (EBV) infection [2]. With recent developments in diagnostic imaging and the use of concurrent chemoradiotherapy, disease control has significantly improved [3]; however, nearly a third of newly diagnosed patients develop local recurrence or distant metastases following treatment $[4,5]$.

EBV encodes nine latent gene products, of which only a handful are expressed in undifferentiated NPC: namely, EBNA1, LMP1, LMP2A, the EBERs and the BARTs [6]. Latent membrane protein 1 (LMP1) is the major transforming protein encoded by EBV and is known for its ability to transform B cells, epithelial cells and fibroblasts in vitro [7] through its constitutive activation of numerous signalling pathways that are frequently deregulated in cancer. These include both the canonical and non-canonical NF-KB pathways [8], the pro-survival PI3K/Akt pathway [9], the stress-related JNK/SAPK pathway [10] and the mitogenic ERK/MAPK [11] and p38-MAPK [12] pathways, which stimulate cell migration and invasion. In addition, LMP1 has been shown to deregulate the pro-fibrotic Smad-independent TGF $\beta$ /activin A signalling pathway and overexpress active $\beta 1$ integrins [13], which may serve to protect epithelial cells from anoikis in order to facilitate metastasis [14].

Controversially, the levels of expression of LMP1 are extremely variable throughout the literature, with reported levels ranging from $20 \%$ to $60 \%$ [15-17]. For years, this has fueled intense debate within the field as to whether LMP1 is indeed implicated in the pathogenesis of NPC. However, findings from 
Dietz et al. (2004) demonstrated the presence of LMP1 in NPC biopsies that had previously been undetected with conventional IHC by using a tyramid-augmented immunohistochemical (TSA-IHC) technique [18]. In addition, LMP1 was found to induce epithelial hyperplasia in transgenic mice at extremely low levels of expression that are virtually undetectable using current methods. Therefore, it is plausible that even extremely low levels of LMP1 expression may facilitate transformation of NPC cells [19].

NPC is described as a lymphoepithelioma on account of its characteristic inflammatory infiltrate, predominantly made up of EBV-specific cytotoxic T cells and a smaller component of regulatory $\mathrm{T}$ cells [20]. However, less is known about other stromal cells that home to the tumour microenvironment (TME) in NPC. Some reports describe a body of activated fibroblasts, also known as cancer-associated fibroblasts (CAFs), surrounding nests of tumour cells in NPC biopsies [21,22], yet the interaction between the virus, its latent gene products and the recruitment and activation of CAFs in NPC pathogenesis is poorly understood. This short opinion piece will review the current body of evidence for the importance of CAFs in the clinical course of NPC, and discuss a putative role for the EBV-encoded oncoprotein, LMP1, in the formation of CAFs in the TME.

\section{Fibroblasts, Myofibroblasts and Cancer-Associated Fibroblasts}

Fibroblasts are one of the most abundant cell types found in the tumour stroma [23,24]. Primarily a source of extracellular matrix (ECM) proteins that provide tissue structure, fibroblasts also serve to determine cell phenotype and function in the wound response to tissue injury [25]. Tumours have been described as "wounds that fail to heal" [26] and fibroblasts have been shown to play an important role in this constitutively active wound response [27].

Following tissue injury, fibroblasts become activated to myofibroblasts, secreting cytokines and growth factors, which stimulate basal epithelial cells to proliferate and migrate, and thereby "close the wound". In addition, they display increased expression and secretion of ECM proteins, which serve as structural support for the migrating epithelial cells, and remodeling enzymes, such as matrix metalloproteinases (MMPs) that help "clear a path" for migration, but myofibroblasts also provide pro-survival signals via outside-in integrin signalling to prevent suspension-induced apoptosis, or anoikis, in migrating epithelial cells [28-30]. Numerous different factors have been identified in the fibroblast activation process in both wound healing and tumourigenesis, including TGF $\beta$ signalling [31], FGF2 activation [32,33], and $\beta 1$ integrin expression [34]. Once the wound healing process has finished, activated myofibroblasts are cleared from the site, either by deactivation back to quiescent fibroblasts or by programmed cell death [28,29].

Activated myofibroblasts are characterised by their expression of alpha smooth muscle actin ( $\alpha$ SMA)-containing stress fibres and a concomitant lack of smooth muscle markers, such as desmin and smooth muscle myosin, that are commonly expressed by inactive fibroblasts [35]. Myofibroblasts may arise from activated fibroblasts [36], or they can originate from the dedifferentiation of epithelial cells having undergone epithelial-to-mesenchymal transition (EMT) [37]. They can also arise from endothelial-to-mesenchymal transition (EndMT) of local endothelial cells [38,39] or from bone-marrow and tissue-derived mesenchymal stem cells (MSCs) [40].

Tumourigenesis mirrors the wound healing programme in many respects, such as with the secretion and deposition of ECM proteins and recruiting an inflammatory infiltrate replete with immune cells [41,42]. However, the key difference that distinguishes tumourigenesis from the natural wound healing process, which is tightly restricted to a defined area, is the ability of cancer cells to expand or migrate away from the primary site and invade neighbouring tissues.

Cancer-associated fibroblasts (CAFs) also share many similarities to activated myofibroblasts, which have been reviewed extensively elsewhere [24]; however, in brief, CAFs also exhibit increased ECM production, and increased secretion of cytokines and growth factors that promote tumour progression [43-45]. CAFs adopt a different immunophenotype when compared with quiescent fibroblasts, which are typically $\mathrm{CD} 34^{+}, \alpha \mathrm{SMA}^{-}$and fibroblast activation protein $(\mathrm{FAP}) \alpha^{-}$, whereas CAFs 
convert to $\mathrm{CD}^{-} 4^{-}, \alpha \mathrm{SMA}^{+}$and $\mathrm{FAP}^{+}$[46]. Whilst the majority of CAFs express $\alpha \mathrm{SMA}$, there is some evidence for a small subpopulation of $\alpha \mathrm{SMA}$-negative CAFs in certain cancers, for example pancreatic cancer [47].

CAFs from different cancer types also express high levels of SDF-1/CXCL12, including breast, endometrial and pancreatic cancer [48-50]. This can result in elevated levels of MMP2 and MMP9 expression, thereby enhancing cell invasion. Moreover, SDF-1/CXCL12 can also induce cancer cell proliferation via a PI3K/Akt and MAPK signalling-dependent mechanism [49].

\section{The Role of CAFs in the NPC Tumour Microenvironment}

In a timely review of the stromal cellular makeup of the TME of EBV-associated cancers, Tan et al. (2018) briefly mention the presence of CAFs in NPC [51]. However, there is a paucity of research in this particular area, having only recently garnered more interest in the field, despite the anecdotal point noted by Pierre Busson a decade ago in respect of the relative ease with which one can recover stromal fibroblasts when compared with malignant NPC cells cultured in vitro [20].

Nonetheless, evidence is emerging in support of the key role that CAFs may play in the pathogenesis of NPC. In a study by Wang et al. (2014), immunohistochemical staining revealed significantly higher levels of $\alpha \mathrm{SMA}$ in the stroma surrounding nests of NPC tumour cells, alongside high levels of SDF-1 (also known as CXCL12) in the tumour cells themselves. The authors also demonstrated a correlation between $\alpha$ SMA and CD34 expression-an indicator of microvessel density used as a measure of neoangiogenesis, lending additional support to the role of CAFs in NPC pathogenesis [21].

SDF-1/CXCL12 is a secreted factor that is implicated in regulating tumourigenesis and stromal interactions in the TME [52]. In breast cancer models, SDF-1/CXCL12 is known to mediate the growth-promoting effects of stromal fibroblasts on cancer cells [48]. CXCR4 is the cognate receptor for SDF-1/CXCL12 and is also implicated in cancer metastasis [53-55]. Indeed, elevated levels of SDF-1/CXCL12 in the TME forms a local concentration gradient along which CXCR4-expressing cells, such as bone marrow-derived mesenchymal stem cells (MSCs) can migrate along, homing to the tumour [56].

Malignant NPC cells frequently overexpress CXCR4; however, CXCR4 often localises to the nuclear compartment in malignant NPC biopsies [57], which raises the question whether this may render them unresponsive to CXCL12. Although SDF-1/CXCL12 is known to be released by CAFs in different cancer settings [48,58], it can also be secreted in a paracrine fashion by cancer cells themselves [59], further supporting the findings from Wang et al. (2014).

In 2017, Chen et al. reported high densities of $\alpha$ SMA-expressing CAFs in less than half of all the NPC biopsies they tested (41.2\%). Interestingly, however, they featured in the majority of metastatic NPC tissues (83.3\%) and high densities also correlated with shorter overall survival and lower 5-year survival rates, suggesting their utility as independent prognostic factors for NPC survival. Curiously, the authors also describe an unusual occurrence whereby a small number of NPC tumour cells expressed $\alpha \mathrm{SMA}$, which is usually reserved for fibroblasts, smooth muscle cells and perivascular cells [22]. This unexpected observation may suggest that NPC tumour cells undergo conversion via an EMT-like mechanism and adopt an $\alpha$ SMA-expressing mesenchymal phenotype, a phenomenon for which Lee et al. (2013) have already demonstrated a precedent in metastatic lung cancer [60].

In a similar vein, Yu et al. (2018) also demonstrated the use of $\alpha$ SMA expression in CAFs, as well as CD163 expression on tumour-associated macrophages (TAMs), as independent predictors of survival in NPC prognostication using tissue microarrays [61]. To date, this is the only study linking CAFs and TAMs in NPC progression and survival, however studies in other cancers describe a crosstalk between resident CAFs and TAMs in the TME. In one such study, the relationship between pro-inflammatory M2 monocyte TAMs and CAFs in prostate cancer is shown to be reciprocal: the M2 TAMs promote the transdifferentiation of fibroblasts to CAFs, and the CAFs, in turn, facilitate monocyte recruitment and macrophage differentiation [62]. Subsequently, together they promote tumourigenesis and metastasis. Similar synergies are observed in other cancers, including bladder cancer, colorectal cancer, 
breast cancer and neuroblastoma [63-66]. The findings presented by Yu et al., whereby the presence of both CAFs and TAMs in NPC correlates with poorer survival rates, suggest that this cooperative crosstalk between the two stromal cell types may occur in NPC as well.

\section{The Putative Role of LMP1 in Driving CAF Formation in NPC}

Whilst relatively little is known about the mechanistic basis for the role of CAFs in NPC progression, even less is known about the interaction between EBV, its latent gene products and the recruitment and activation of CAFs in NPC. However, there are a number of interesting synergies between the mechanisms involved in CAF-mediated tumourigenesis and the signalling pathways engaged by LMP1. The following section will discuss speculative roles for LMP1 in driving CAF formation in NPC that deserve closer investigation.

Despite the variable levels of LMP1 expression in NPC biopsies reported in the literature, which likely reflect the sensitivity and specificity of the methods of detection used to identify LMP1-positivity [67], it is widely believed that LMP1 expression plays an important role during the early disease process, both in the malignant transformation of nasopharyngeal epithelial cells, as well as recruiting and activating the characteristic inflammatory infiltrate. Unlike late stage disease, where LMP1 expression is highly heterogeneous and often restricted to a small number of NPC cells [68], during early stage disease LMP1 expression is more uniform [69,70], and its expression in premalignant lesions facilitates metastasis earlier in the disease process, suggesting a link to the highly metastatic nature of NPC [71,72].

In an older study, $\mathrm{Hu}$ et al. (1995) found LMP1-positive tumours to be more aggressive than their LMP1-negative counterparts, as demonstrated by their faster, more expansive growth and their tendency to invade more frequently at sites outside the nasopharynx. Intriguingly, despite this aggressive phenotype, patients with LMP1-positive tumours had a better prognosis with fewer recurrences [73].

In vitro studies have shown that high levels of LMP1 expression are toxic in some epithelial cell lines and that they may induce a host immune response [74,75]. Moreover, even low levels of LMP1 expression have been shown to be sufficient to elicit tumourigenic effects. For example, very low levels of LMP1 expression in the NP69 nasopharyngeal epithelial cell line can induce anchorage-independent growth, morphological alterations and an invasive phenotype in vitro [70], and in transgenic mice, LMP1 has been shown to induce epithelial hyperplasia at extremely low expression levels [19]. In addition to the possibility that even extremely low levels of LMP1 expression can facilitate the transformation of NPC cells, it is plausible that EBV may temporally modulate the expression of LMP1 at different stages of NPC pathogenesis: with elevated levels during early stage disease to facilitate host cell malignant transformation, and subsequently downregulating LMP1 expression in late stage disease to avoid eliciting the host immune response.

In line with previous observations in which NPC biopsies displayed SDF-1/CXCL12-expressing tumour cell nests surrounded by $\alpha$ SMA-expressing CAFs [21,57], it is interesting to note that LMP1 expression in NPC biopsies also correlates with higher levels of CXCR4 and its nuclear localisation, but intriguingly, there was no correlation with SDF-1/CXCL12 expression [76], suggesting that LMP1 does not itself modulate the expression of this growth-promoting chemokine. However, LMP1 has been shown to upregulate CXCR4 mRNA in murine embryonic fibroblasts in an NF- $\mathrm{BB}-$ dependent manner [77], and in NPC cells, LMP1 is able to regulate CXCR4 activity through post-translational modification, resulting in enhanced metastatic characteristics [78]. Thus, it is possible that LMP1-mediated overexpression of CXCR4, the cognate receptor for SDF-1/CXCL12, is involved in amplifying the response of NPC cells to CAF-derived SDF-1/CXCL12.

In addition to the well-known signalling pathways engaged by LMP1 that are classically deregulated in cancer [79], more recent studies have identified novel signalling capabilities for this transforming oncoprotein. LMP1 has previously been shown to modulate the expression and secretion of TGF $\beta 1$, as well as enhance the TGF $\beta$-dependent modulation of ERK-MAPK $[13,80]$. TGF $\beta$ is 
a pleiotropic cytokine that displays context-dependent effects on cell growth, differentiation and maturation, and is an important mediator of CAF-driven tumourigenesis [81].

In the first instance, TGF $\beta$ is known to be involved in activating fibroblasts [31]. During the wound healing process, TGF $\beta 1$ induces wound contraction by fibroblasts as well as ECM protein deposition and keratinocyte migration via integrin activation [82]. LMP1 has also been shown to increase the expression and deposition of fibronectin via a Smad-independent TGF $\beta$-mediated mechanism, as well as upregulating the expression of active $\beta 1$ integrins, the major fibronectin receptor, on the surface of epithelial cells [13]. Therefore, it is intriguing to consider whether LMP1-mediated TGF $\beta$ secretion could activate fibroblasts in the NPC TME, enhancing contractility and tumour cell migration.

The secretion of TGF $\beta 1$ by CAFs drives EMT in breast cancer cells, resulting in elevated levels of cell-ECM adhesion, breast cancer cell invasion and migration, effects which could be abrogated by inhibiting TGF $\beta$ signalling [83]. Similar effects of CAF-derived TGF $\beta$ are also seen in other cancers, including gastric, colorectal and bladder cancer [84-87].

By contrast, LMP1 has been shown to induce EMT in epithelial cells via an ERK-MAPK-dependent mechanism, but inhibition of TGF $\beta$ signalling had no effect on reversing the EMT phenotype [14]. Taken together, it is tempting to speculate whether LMP1 might drive EMT directly, via ERK-MAPK signalling in epithelial cells, or indirectly via the recruitment and activation of CAFs, stimulating their release of TGF $\beta$ to act in a paracrine manner on NPC cells in the TME, or indeed a synergistic combination of the two. These questions remain unanswered at present, but future studies may reveal novel insights into the role of LMP1 in mediating CAF-driven EMT.

Another family of soluble factors that play an important role in CAF-driven tumourigenesis is the fibroblast growth factor (FGF) family of signalling proteins. The secretion of FGF family members by CAFs has been shown in multiple different cancer settings: ovarian CAFs secrete FGF-1, leading to phosphorylation of the receptor, FGFR4 [88]; breast CAFs secrete FGF-2 and signal via both FGFR1 and FGFR2 [89,90]; and colon CAFs secrete FGF-1 and -3, and signal via FGFR4 [91]. CAFs also express a surface-associated FGF2 that is not typically secreted into the extracellular microenvironment. In one study involving the co-culture of colorectal cancer cells with CAFs expressing FGF-2, the phenotype of the cancer cells altered to become more elongated, they were able to migrate longer distances, and invaded into Matrigel supplemented with fibroblasts. This interaction between the cancer cells and the fibroblasts was mediated via $\alpha v \beta 5$ integrin [92].

LMP1 has been shown to induce FGFR1 expression and phosphorylation in NP69 nasopharyngeal epithelial cells, as well as upregulating FGF-2, leading to constitutive activation of the FGFR1 signalling pathway. Inhibition of FGFR1 in this cell system abrogated LMP1's ability to mediate aerobic glycolysis, cellular transformation, cell migration and invasion, thereby suggesting a novel role for FGF2/FGFR1 signalling in NPC pathogenesis. The authors also demonstrated high levels of phosphorylated FGFR1 in NPC biopsies that correlated with LMP1 expression [93]. Therefore, it is interesting to consider whether LMP1-mediated FGF2/FGFR1 signalling is serving as a potential mechanism for amplifying the effect of CAF-mediated tumourigenesis in the NPC TME.

\section{Conclusions and Future Perspectives}

In summary, CAFs are a prominent feature in NPC biopsies, correlating with poorer prognosis, therefore supporting their role in NPC pathogenesis. NPCs with high levels of LMP1 expression tend to display more aggressive phenotypic features, yet curiously, patients with high LMP1 have a better prognosis. However, since even low levels of LMP1 expression can exert tumourigenic effects, it is possible that this is sufficient to drive NPC transformation and the recruitment and activation of CAFs in the TME. Numerous signalling pathways involved in CAF activation and CAF-driven EMT are also engaged by LMP1, as summarised in Figure 1, yet the link between LMP1 signalling and CAF formation remains unknown. 
(a)

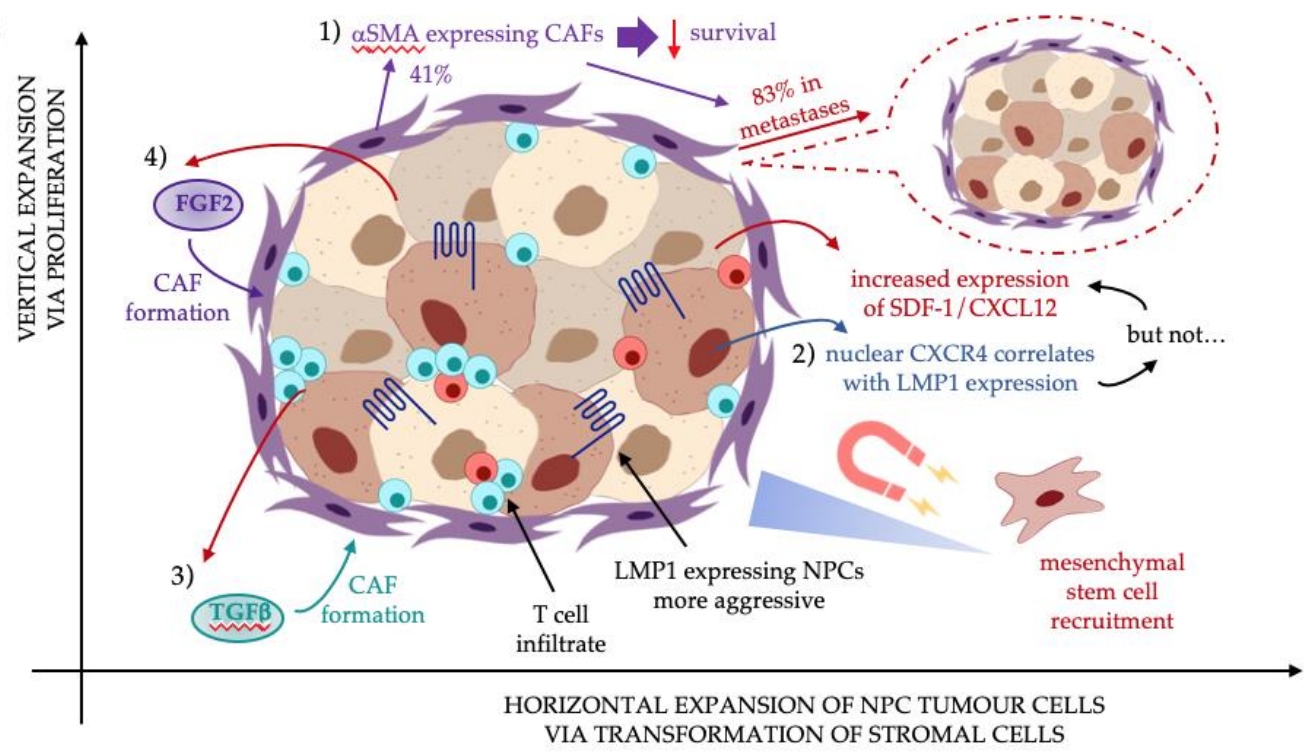

(b)

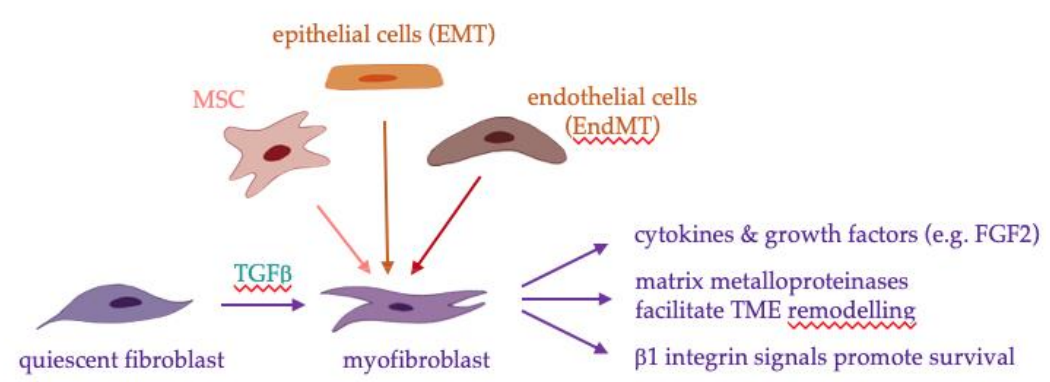

Figure 1. The putative role for LMP1 in CAF formation in NPC: (a) From top-left in a clockwise direction: (1) $\alpha \mathrm{SMA}$ expression correlates with lower survival rates. High densities of CAFs were seen in $41 \%$ of NPC biopsies, yet $83 \%$ of metastatic NPC [22]; (2) NPCs display elevated levels of SDF-1/CXCL12 and its cognate receptor, CXCR4. LMP1 expression correlates with nuclear CXCR4 expression, but intriguingly not with SDF-1/CXCL12 [76]. Increased SDF-1/CXCL12 in the TME forms a concentration gradient along which CXCR4-expressing mesenchymal stem cells (MSCs) home to the tumour [56]; (3) epithelial cells expressing LMP1 secrete TGF $\beta 1$, a key driver in CAF formation, but its role in NPC CAF genesis remains unknown [13]; (4) LMP1 also modulates expression of FGF2 and its receptor, FGFR1, which suggests it may be implicated in CAF formation [93]; (b) Potential sources of CAFs in the TME include quiescent fibroblasts stimulated by TGF $\beta$, mesenchymal stem cells, epithelial cells via EMT, or endothelial cells via EndMT [36-40].

There are a number of unanswered questions in this area. (1) Could LMP1 be driving the horizontal expansion of NPC tumour cells via transformation of stromal cells in the TME in addition to its already known role in promoting vertical expansion via proliferation and the transfer of genetic and epigenetic changes to progeny cells? (2) How much LMP1 is "enough" to elicit transformation and could even low levels be sufficient to recruit and transform fibroblasts in the TME? (3) Could the NPC cells expressing $\alpha \mathrm{SMA}$ have originated from CAFs or even mesenchymal stem cells that have been transformed to adopt a carcinoma-like phenotype? (4) What role, if any, do other EBV-encoded latent gene products play in CAF formation? Therefore, there is a compelling argument for prioritising these research questions in future investigations, which may reveal novel insights into the role of EBV and LMP1 in CAF-driven NPC tumourigenesis.

Funding: This research received no external funding.

Conflicts of Interest: The author declares no conflict of interest. 


\section{References}

1. Mahdavifar, N.; Towhidi, F.; Makhsosi, B.R.; Pakzad, R.; Moini, A.; Ahmadi, A.; Lotfi, S.; Salehiniya, H. Incidence and Mortality of Nasopharynx Cancer and Its Relationship With Human Development Index in the World in 2012. World J. Oncol. 2016, 7, 109-118. [CrossRef]

2. Wu, L.; Li, C.; Pan, L. Nasopharyngeal carcinoma: A review of current updates. Exp. Ther. Med. 2018, 15, 3687-3692. [CrossRef] [PubMed]

3. Lee, A.W.M.; Lau, W.H.; Tung, S.Y.; Chua, D.T.T.; Chappell, R.; Xu, L.; Siu, L.; Sze, W.M.; Leung, T.W.; Sham, J.S.; et al. Preliminary Results of a Randomized Study on Therapeutic Gain by Concurrent Chemotherapy for Regionally-Advanced Nasopharyngeal Carcinoma: NPC-9901 Trial by the Hong Kong Nasopharyngeal Cancer Study Group. J. Clin. Oncol. 2005, 23, 6966-6975. [CrossRef] [PubMed]

4. $\quad$ Lin, J.-C.; Jan, J.-S.; Hsu, C.-Y.; Liang, W.-M.; Jiang, R.-S.; Wang, W.-Y. Phase III Study of Concurrent Chemoradiotherapy Versus Radiotherapy Alone for Advanced Nasopharyngeal Carcinoma: Positive Effect on Overall and Progression-Free Survival. J. Clin. Oncol. 2003, 21, 631-637. [CrossRef] [PubMed]

5. Ma, S.-X.; Zhou, T.; Huang, Y.; Yang, Y.-P.; Zhan, J.-H.; Zhang, Y.-X.; Zhang, Z.H.; Zhao, Y.Y.; Fang, W.F.; Ma, Y.X.; et al. The efficacy of first-line chemotherapy in recurrent or metastatic nasopharyngeal carcinoma: A systematic review and meta-analysis. Ann. Transl. Med. 2018, 6, 201. [CrossRef] [PubMed]

6. Tsao, S.W.; Tsang, C.M.; Lo, K.W. Epstein-Barr virus infection and nasopharyngeal carcinoma. Philos. Trans. R. Soc. Lond. B Biol. Sci. 2017, 372. [CrossRef] [PubMed]

7. Wang, D.; Liebowitz, D.; Kieff, E. An EBV membrane protein expressed in immortalized lymphocytes transforms established rodent cells. Cell 1985, 43, 831-840. [CrossRef]

8. Lavorgna, A.; Harhaj, E.W. EBV LMP1: New and shared pathways to NF- B activation. Proc. Natl. Acad. Sci. USA 2012, 109, 2188-2189. [CrossRef]

9. Dawson, C.W.; Tramountanis, G.; Eliopoulos, A.G.; Young, L.S. Epstein-Barr virus latent membrane protein 1 (LMP1) activates the phosphatidylinositol 3-kinase/Akt pathway to promote cell survival and induce actin filament remodeling. J. Biol Chem. 2003, 278, 3694-3704. [CrossRef]

10. Eliopoulos, A.G.; Young, L.S. Activation of the cJun N-terminal kinase (JNK) pathway by the Epstein-Barr virus-encoded latent membrane protein 1 (LMP1). Oncogene 1998, 16, 1731-1742. [CrossRef]

11. Dawson, C.W.; Laverick, L.; Morris, M.A.; Tramoutanis, G.; Young, L.S. Epstein-Barr virus-encoded LMP1 regulates epithelial cell motility and invasion via the ERK-MAPK pathway. J. Virol. 2008, 82, 3654-3664. [CrossRef] [PubMed]

12. Eliopoulos, A.G.; Gallagher, N.J.; Blake, S.M.; Dawson, C.W.; Young, L.S. Activation of the p38 mitogen-activated protein kinase pathway by Epstein-Barr virus-encoded latent membrane protein 1 coregulates interleukin-6 and interleukin-8 production. J. Biol Chem. 1999, 274, 16085-16096. [CrossRef]

13. Morris, M.A.; Dawson, C.W.; Laverick, L.; Davis, A.M.; Dudman, J.P.R.; Raveenthiraraj, S.; Ahmad, Z.; Yap, L.-F.; Young, L.S. The Epstein-Barr virus encoded LMP1 oncoprotein modulates cell adhesion via regulation of activin A/TGF $\beta$ and $\beta 1$ integrin signalling. Sci. Rep. 2016, 6, 19533. [CrossRef]

14. Morris, M.A.; Laverick, L.; Wei, W.; Davis, A.M.; O’Neill, S.; Wood, L.; Wright, J.; Wright, C.W.; Young, L.S. The EBV-encoded oncoprotein, LMP1, induces an epithelial-to-mesenchymal transition (EMT) via its CTAR1 domain through integrin-mediated ERK-MAPK signalling. Cancers (Basel) 2018, 10, 130. [CrossRef] [PubMed]

15. Murono, Y.; Yoshizaki, T.; Park, C.-S.; Furukawa, M. Association of Epstein-Barr virus infection with p53 protein accumulation but not bcl-2 protein in nasopharyngeal carcinoma. Histopathology 1999, 34, $432-438$. [CrossRef] [PubMed]

16. Niedobitek, G. Epstein-Barr virus infection in the pathogenesis of nasopharyngeal carcinoma. Mol. Pathol. 2000, 53, 248-254. [CrossRef] [PubMed]

17. Sarac, S.; Akyol, M.U.; Kanbur, B.; Poyraz, A.; Akyol, G.; Yilmaz, T.; Sungur, A. Bcl-2 and LMP1 expression in nasopharyngeal carcinomas. Am. J. Otolaryngol. 2001, 22, 377-382. [CrossRef]

18. Dietz, A.; Logothetis, C.A.; Helbig, M.; Flechtenmacher, C.; Rudat, V.; Dollner, R.; Wallner, F.; Bosch, F.X. Prognostic Impact of EBV-Related LMP-1, Histologic Type, and Environmental Factors in Nasopharyngeal Carcinoma in a German Population. Oncol. Res. Treat. 2004, 27, 345-350. [CrossRef]

19. Stevenson, D.; Charalambous, C.; Wilson, J.B. Epstein-Barr Virus Latent Membrane Protein 1 (CAO) Up-regulates VEGF and TGF $\alpha$ Concomitant with Hyperlasia, with Subsequent Up-regulation of p16 and MMP9. Cancer Res. 2005, 65, 8826-8835. [CrossRef] 
20. Gourzones, C.; Jihène, K.; Friboulet, L.; Jlidi, R.; Busson, P. Cellular Interactions in Nasopharyngeal Carcinomas; Springer: New York, NY, USA, 2013.

21. Wang, S.; Ma, N.; Kawanishi, S.; Hiraku, Y.; Oikawa, S.; Xie, Y.; Zhang, Z.; Huang, G.; Murata, M. Relationships of Alpha-SMA-Positive Fibroblasts and SDF-1-Positive Tumor Cells with Neoangiogenesis in Nasopharyngeal Carcinoma. Biomed. Res. Int. 2014, 2014, 507353. [CrossRef]

22. Chen, J.; Yang, P.; Xiao, Y.; Zhang, Y.; Liu, J.; Xie, D.; Cai, M.; Zhang, X. Overexpression of $\alpha$-sma-positive fibroblasts (CAFs) in Nasopharyngeal Carcinoma Predicts Poor Prognosis. J. Cancer 2017, 8, 3897-3902. [CrossRef] [PubMed]

23. Bhowmick, N.A.; Neilson, E.G.; Moses, H.L. Stromal fibroblasts in cancer initiation and progression. Nature 2004, 432, 332-337. [CrossRef] [PubMed]

24. Liu, T.; Han, C.; Wang, S.; Fang, P.; Ma, Z.; Xu, L.; Yin, R. Cancer-associated fibroblasts: An emerging target of anti-cancer immunotherapy. J. Hematol. Oncol. 2019, 12, 86. [CrossRef] [PubMed]

25. Li, B.; Wang, J.H.-C. Fibroblasts and myofibroblasts in wound healing: Force generation and measurement. J. Tissue Viability 2011, 20, 108-120. [CrossRef] [PubMed]

26. Flier, J.S.; Underhill, L.H.; Dvorak, H.F. Tumors: Wounds That Do Not Heal. N. Engl. J. Med. 1986, 315, 1650-1659. [CrossRef] [PubMed]

27. Foster, D.S.; Jones, R.E.; Ransom, R.C.; Longaker, M.T.; Norton, J.A. The evolving relationship of wound healing and tumor stroma. JCI Insight 2018, 3. [CrossRef]

28. Darby, I.A.; Laverdet, B.; Bonté, F.; Desmoulière, A. Fibroblasts and myofibroblasts in wound healing. Clin. Cosmet Investig. Dermatol. 2014, 7, 301-311.

29. Desmoulière, A. Factors influencing myofibroblast differentiation during wound healing and fibrosis. Cell Biol. Int. 1995, 19, 471. [CrossRef]

30. Miles, F.L.; Sikes, R.A. Insidious changes in stromal matrix fuel cancer progression. Mol. Cancer Res. 2014, 12, 297-312. [CrossRef]

31. Rønnov-Jessen, L.; Petersen, O.W. Induction of alpha-smooth muscle actin by transforming growth factor-beta 1 in quiescent human breast gland fibroblasts. Implications for myofibroblast generation in breast neoplasia. Lab. Investig. 1993, 68, 696-707.

32. Brennen, W.N.; Isaacs, J.T.; Denmeade, S.R. Rationale behind targeting fibroblast activation protein-expressing carcinoma-associated fibroblasts as a novel chemotherapeutic strategy. Mol. Cancer Ther. 2012, 11, 257-266. [CrossRef] [PubMed]

33. Wang, X.; Zhu, Y.; Sun, C.; Wang, T.; Shen, Y.; Cai, W.; Sun, J.; Chi, L.; Wang, H.; Song, N.; et al. Feedback Activation of Basic Fibroblast Growth Factor Signaling via the Wnt/ $\beta$-Catenin Pathway in Skin Fibroblasts. Front. Pharm. 2017, 8, 32. [CrossRef] [PubMed]

34. Liu, S.; Xu, S.-W.; Blumbach, K.; Eastwood, M.; Denton, C.P.; Eckes, B.; Krieg, T.; Abraham, D.J.; Leask, A. Expression of integrin 1 by fibroblasts is required for tissue repair in vivo. J. Cell Sci. 2010, 123, 3674-3682. [CrossRef] [PubMed]

35. McAnulty, R.J. Fibroblasts and myofibroblasts: Their source, function and role in disease. Int. J. Biochem. Cell Biol. 2007, 39, 666-671. [CrossRef] [PubMed]

36. Fukino, K.; Shen, L.; Matsumoto, S.; Morrison, C.D.; Mutter, G.L.; Eng, C. Combined Total Genome Loss of Heterozygosity Scan of Breast Cancer Stroma and Epithelium Reveals Multiplicity of Stromal Targets. Cancer Res. 2004, 64, 7231-7236. [CrossRef] [PubMed]

37. Petersen, O.W.; Nielsen, H.L.; Gudjonsson, T.; Villadsen, R.; Rønnov-Jessen, L.; Bissell, M.J. The plasticity of human breast carcinoma cells is more than epithelial to mesenchymal conversion. Breast Cancer Res. 2001, 3, 213. [CrossRef] [PubMed]

38. Zeisberg, E.M.; Tarnavski, O.; Zeisberg, M.; Dorfman, A.L.; McMullen, J.R.; Gustafsson, E.; Chandraker, A.; Yuan, X.; Pu, W.T.; Roberts, A.B.; et al. Endothelial-to-mesenchymal transition contributes to cardiac fibrosis. Nat. Med. 2007, 13, 952-961. [CrossRef] [PubMed]

39. Zeisberg, E.M.; Potenta, S.; Xie, L.; Zeisberg, M.; Kalluri, R. Discovery of Endothelial to Mesenchymal Transition as a Source for Carcinoma-Associated Fibroblasts. Cancer Res. 2007, 67, 10123-10128. [CrossRef]

40. Quante, M.; Tu, S.P.; Tomita, H.; Gonda, T.; Wang, S.S.W.; Takashi, S.; Baik, G.H.; Shibata, W.; DiPrete, B.; Betz, K.S.; et al. Bone marrow-derived myofibroblasts contribute to the mesenchymal stem cell niche and promote tumor growth. Cancer Cell 2011, 19, 257-272. [CrossRef] 
41. Schäfer, M.; Werner, S. Cancer as an overhealing wound: An old hypothesis revisited. Nat. Rev. Mol. Cell Biol. 2008, 9, 628-638. [CrossRef]

42. Arnold, K.M.; Opdenaker, L.M.; Flynn, D.; Sims-Mourtada, J. Wound healing and cancer stem cells: Inflammation as a driver of treatment resistance in breast cancer. Cancer Growth Metastasis 2015, 8, 1-13. [CrossRef] [PubMed]

43. Bauer, M.; Su, G.; Casper, C.; He, R.; Rehrauer, W.; Friedl, A. Heterogeneity of gene expression in stromal fibroblasts of human breast carcinomas and normal breast. Oncogene 2010, 29, 1732-1740. [CrossRef]

44. Xing, F.; Saidou, J.; Watabe, K. Cancer associated fibroblasts (CAFs) in tumor microenvironment. Front. Biosci. (Landmark Ed.) 2010, 15, 166-179. [CrossRef] [PubMed]

45. Pidsley, R.; Lawrence, M.G.; Zotenko, E.; Niranjan, B.; Statham, A.; Song, J.; Chabanon, R.M.; Qu, W.; Wang, H.; Richards, M.; et al. Enduring epigenetic landmarks define the cancer microenvironment. Genome Res. 2018, 28, 625-638. [CrossRef] [PubMed]

46. Hua, X.; Huang, X.; Liao, Z.; Xian, Q.; Yu, L. Changes of fibroblast immunophenotype and their clinical significance in stromal remodeling of breast tumors. Zhonghua Zhong Liu Za Zhi 2014, 36, 834-838. [PubMed]

47. Öhlund, D.; Handly-Santana, A.; Biffi, G.; Elyada, E.; Almeida, A.S.; Ponz-Sarvise, M.; Corbo, V.; Oni, T.E.; Hearn, S.A.; Lee, E.J.; et al. Distinct populations of inflammatory fibroblasts and myofibroblasts in pancreatic cancer. J. Exp. Med. 2017, 214, 579-596.

48. Orimo, A.; Gupta, P.B.; Sgroi, D.C.; Arenzana-Seisdedos, F.; Delaunay, T.; Naeem, R.; Carey, V.J.; Richardson, A.L.; Weinberg, R.A. Stromal Fibroblasts Present in Invasive Human Breast Carcinomas Promote Tumor Growth and Angiogenesis through Elevated SDF-1/CXCL12 Secretion. Cell 2005, 121, 335-348. [CrossRef]

49. Teng, F.; Tian, W.-Y.; Wang, Y.-M.; Zhang, Y.-F.; Guo, F.; Zhao, J.; Gao, C.; Xue, F.-X. Cancer-associated fibroblasts promote the progression of endometrial cancer via the SDF-1/CXCR4 axis. J. Hematol. Oncol. 2016, 9, 8. [CrossRef]

50. Wei, L.; Ye, H.; Li, G.; Lu, Y.; Zhou, Q.; Zheng, S.; Lin, Q.; Liu, Y.; Li, Z.; Chen, R. Cancer-associated fibroblasts promote progression and gemcitabine resistance via the SDF-1/SATB-1 pathway in pancreatic cancer. Cell Death Dis. 2018, 9, 1065. [CrossRef]

51. Tan, G.W.; Visser, L.; Tan, L.P.; van den Berg, A.; Diepstra, A. The Microenvironment in Epstein-Barr Virus-Associated Malignancies. Pathogens 2018, 7, 40. [CrossRef]

52. Teicher, B.A.; Fricker, S.P. CXCL12 (SDF-1)/CXCR4 Pathway in Cancer. Clin. Cancer Res. 2010, 16, $2927-2931$. [CrossRef] [PubMed]

53. Müller, A.; Homey, B.; Soto, H.; Ge, N.; Catron, D.; Buchanan, M.E.; McClanahan, T.; Murphy, E.; Yuan, W.; Wagner, S.N. Involvement of chemokine receptors in breast cancer metastasis. Nature 2001, 410, 50-56. [CrossRef] [PubMed]

54. Kucia, M.; Jankowski, K.; Reca, R.; Wysoczynski, M.; Bandura, L.; Allendorf, D.J.; Zhang, J.; Ratajczak, J.; Ratajczak, M.Z. CXCR4-SDF-1 signalling, locomotion, chemotaxis and adhesion. J. Mol. Histol. 2004, 35, 233-245. [CrossRef] [PubMed]

55. Chatterjee, S.; Behnam Azad, B.; Nimmagadda, S. The intricate role of CXCR4 in cancer. Adv. Cancer Res. 2014, 124, 31-82. [PubMed]

56. Domanska, U.M.; Kruizinga, R.C.; Nagengast, W.B.; Timmer-Bosscha, H.; Huls, G.; de Vries, E.G.E.; Walenkamp, A.M. A review on CXCR4/CXCL12 axis in oncology: No place to hide. Eur. J. Cancer 2013, 49, 219-230. [CrossRef]

57. Wang, N.; Wu, Q.-L.; Fang, Y.; Mai, H.-Q.; Zeng, M.-S.; Shen, G.-P.; Hou, J.-H.; Zeng, Y.-X. Expression of chemokine receptor CXCR4 in nasopharyngeal carcinoma: Pattern of expression and correlation with clinical outcome. J. Transl. Med. 2005, 3, 26. [CrossRef]

58. Saigusa. Cancer-associated fibroblasts correlate with poor prognosis in rectal cancer after chemoradiotherapy. Int. J. Oncol. 2011, 38, 655-663.

59. Lee, B.-C.; Lee, T.-H.; Avraham, S.; Avraham, H.K. Involvement of the chemokine receptor CXCR4 and its ligand stromal cell-derived factor 1alpha in breast cancer cell migration through human brain microvascular endothelial cells. Mol. Cancer Res. 2004, 2, 327-338.

60. Lee, H.W.; Park, Y.M.; Lee, S.J.; Cho, H.J.; Kim, D.-H.; Lee, J.-I.; Kang, M.-S.; Seol, H.J.; Shim, Y.M.; Nam, D.-H.; et al. Alpha-Smooth Muscle Actin (ACTA2) Is Required for Metastatic Potential of Human Lung Adenocarcinoma. Clin. Cancer Res. 2013, 19, 5879-5889. [CrossRef] 
61. Yu, Y.; Ke, L.; Lv, X.; Ling, Y.H.; Lu, J.; Liang, H.; Qiu, W.; Huang, X.; Liu, G.; Li, W.; et al. The prognostic significance of carcinoma-associated fibroblasts and tumor-associated macrophages in nasopharyngeal carcinoma. Cancer Manag. Res. 2018, 10, 1935-1946. [CrossRef]

62. Comito, G.; Giannoni, E.; Segura, C.P.; Barcellos-de-Souza, P.; Raspollini, M.R.; Baroni, G.; Lanciotti, M.; Serni, S.; Chiarugi, P. Cancer-associated fibroblasts and M2-polarized macrophages synergize during prostate carcinoma progression. Oncogene 2014, 33, 2423-2431. [CrossRef] [PubMed]

63. Herrera, M.; Herrera, A.; Domínguez, G.; Silva, J.; García, V.; García, J.M.; Gómez, I.; Soldevilla, B.; Muñoz, C.; Provencio, M.; et al. Cancer-associated fibroblast and M2 macrophage markers together predict outcome in colorectal cancer patients. Cancer Sci. 2013, 104, 437-444. [CrossRef] [PubMed]

64. Rama-Esendagli, D.; Esendagli, G.; Yilmaz, G.; Guc, D. Spheroid formation and invasion capacity are differentially influenced by co-cultures of fibroblast and macrophage cells in breast cancer. Mol. Biol. Rep. 2014, 41, 2885-2892. [CrossRef] [PubMed]

65. Hashimoto, O.; Yoshida, M.; Koma, Y.-I.; Yanai, T.; Hasegawa, D.; Kosaka, Y.; Nishimura, N.; Yokozaki, H. Collaboration of cancer-associated fibroblasts and tumour-associated macrophages for neuroblastoma development. J. Pathol. 2016, 240, 211-223. [CrossRef]

66. Miyake, M.; Hori, S.; Morizawa, Y.; Tatsumi, Y.; Nakai, Y.; Anai, S.; Torimoto, K.; Aoki, K.; Tanaka, N.; Shimada, K.; et al. CXCL1-Mediated Interaction of Cancer Cells with Tumor-Associated Macrophages and Cancer-Associated Fibroblasts Promotes Tumor Progression in Human Bladder Cancer. Neoplasia 2016, 18, 636-646. [CrossRef]

67. Tao, Q.; Young, L.S.; Woodman, C.B.J.; Murray, P.G. Epstein-Barr virus (EBV) and its associated human cancers-Genetics, epigenetics, pathobiology and novel therapeutics. Front. Biosci. 2006, 11, $2672-2713$. [CrossRef]

68. Niedobitek, G.; Meru, N.; Delecluse, H.J. Epstein-Barr virus infection and human malignancies. Int. J. Exp. Pathol. 2001, 149-170. [CrossRef]

69. Pathmanathan, R.; Prasad, U.; Chandrika, G.; Sadler, R.; Flynn, K.; Raab-Traub, N. Undifferentiated, nonkeratinizing, and squamous cell carcinoma of the nasopharynx. Variants of Epstein-Barr virus-infected neoplasia. Am. J. Pathol. 1995, 146, 1355-1367.

70. Tsao, S.W.; Tramoutanis, G.; Dawson, C.W.; Lo, A.K.; Huang, D.P. The significance of LMP1 expression in nasopharyngeal carcinoma. Semin. Cancer Biol. 2002, 12, 473-487. [CrossRef]

71. Robertson, E.S. Epstein-Barr Virus; Caister Academic Press: Philadelphia, PA, USA, 2005; 770p.

72. Nakanishi, Y.; Wakisaka, N.; Kondo, S.; Endo, K.; Sugimoto, H.; Hatano, M.; Ueno, T.; Ishikawa, K.; Yoshizaki, T. Progression of understanding for the role of Epstein-Barr virus and management of nasopharyngeal carcinoma. Cancer Metastasis Rev. 2017, 36, 435-447. [CrossRef]

73. Hu, L.F.; Chen, F.; Zhen, Q.F.; Zhang, Y.W.; Luo, Y.; Zheng, X.; Winberg, G.; Ernberg, I.; Klein, G. Differences in the growth pattern and clinical course of EBV-LMP1 expressing and non-expressing nasopharyngeal carcinomas. Eur. J. Cancer 1995, 31, 658-660. [CrossRef]

74. Hammerschmidt, W.; Sugden, B.; Baichwal, V.R. The transforming domain alone of the latent membrane protein of Epstein-Barr virus is toxic to cells when expressed at high levels. J. Virol. 1989, 63, 2469-2475. [PubMed]

75. Liu, Y.; Wang, X.; Lo, A.K.F.; Wong, Y.C.; Cheung, A.L.M.; Tsao, S.W. Latent membrane protein-1 of Epstein-Barr virus inhibits cell growth and induces sensitivity to cisplatin in nasopharyngeal carcinoma cells. J. Med. Virol. 2002, 66, 63-69. [CrossRef] [PubMed]

76. Li, J.; Zhang, X.; Xie, D.; Deng, H.; Gao, Y.; Chen, Q.; Huang, W.-L.; Masucci, M.G.; Zeng, Y.-X. Expression of immune-related molecules in primary EBV positive chinese nasopharyngeal carcinoma: Associated with latent membrane protein 1 (LMP1) expression. Cancer Biol. Ther. 2007, 6, 1997-2004. [CrossRef] [PubMed]

77. Luftig, M.; Yasui, T.; Soni, V.; Kang, M.-S.; Jacobson, N.; Cahir-McFarland, E.; Seed, B.; Kieff, E. Epstein-Barr virus latent infection membrane protein 1 TRAF-binding site induces NIK/IKK -dependent noncanonical NF- B activation. Proc. Natl. Acad. Sci. USA 2004, 101, 141-146. [CrossRef] [PubMed]

78. Xu, J.; Deng, X.; Tang, M.; Li, L.; Xiao, L.; Yang, L.; Zhong, J.; Bode, A.M.; Dong, Z.; Tao, Y.; et al. Tyrosylprotein sulfotransferase-1 and tyrosine sulfation of chemokine receptor 4 are induced by Epstein-Barr virus encoded latent membrane protein 1 and associated with the metastatic potential of human nasopharyngeal carcinoma. PLoS ONE 2013, 8, e56114. [CrossRef] [PubMed] 
79. Morris, M.A.; Dawson, C.W.; Young, L.S. Role of the Epstein-Barr virus-encoded latent membrane protein-1 LMP1, in the pathogenesis of nasopharyngeal carcinoma. Future Oncol. 2009, 5, 811-825. [CrossRef]

80. Sides, M.D.; Klingsberg, R.C.; Shan, B.; Gordon, K.A.; Nguyen, H.T.; Lin, Z.; Takahashi, T.; Flemington, E.K.; Lasky, J.A. The Epstein-Barr virus latent membrane protein 1 and transforming growth factor- $\beta 1$ synergistically induce epithelial-mesenchymal transition in lung epithelial cells. Am. J. Respir Cell Mol. Biol. 2011, 44, 852-862. [CrossRef]

81. Fiori, M.E.; Di Franco, S.; Villanova, L.; Bianca, P.; Stassi, G.; De Maria, R. Cancer-associated fibroblasts as abettors of tumor progression at the crossroads of EMT and therapy resistance. Mol. Cancer 2019, 18, 70. [CrossRef]

82. Pakyari, M.; Farrokhi, A.; Maharlooei, M.K.; Ghahary, A. Critical Role of Transforming Growth Factor Beta in Different Phases of Wound Healing. Adv. Wound Care 2013, 2, 215-224. [CrossRef]

83. Yu, Y.; Xiao, C.-H.; Tan, L.-D.; Wang, Q.-S.; Li, X.-Q.; Feng, Y.-M. Cancer-associated fibroblasts induce epithelial-mesenchymal transition of breast cancer cells through paracrine TGF- $\beta$ signalling. Br. J. Cancer 2014, 110, 724-732. [CrossRef] [PubMed]

84. Shimao, Y.; Nabeshima, K.; Inoue, T.; Koono, M. Role of fibroblasts in HGF/SF-induced cohort migration of human colorectal carcinoma cells: Fibroblasts stimulate migration associated with increased fibronectin production via upregulated TGF-?1. Int. J. Cancer 1999, 82, 449-458. [CrossRef]

85. Fuyuhiro, Y.; Yashiro, M.; Noda, S.; Matsuoka, J.; Hasegawa, T.; Kato, Y.; Sawada, T.; Hirakawa, K. Cancer-associated orthotopic myofibroblasts stimulates the motility of gastric carcinoma cells. Cancer Sci. 2012, 103, 797-805. [CrossRef] [PubMed]

86. Kim, S.-A.; Lee, E.K.; Kuh, H.-J. Co-culture of 3D tumor spheroids with fibroblasts as a model for epithelial-mesenchymal transition in vitro. Exp. Cell Res. 2015, 335, 187-196. [CrossRef]

87. Zhuang, J.; Lu, Q.; Shen, B.; Huang, X.; Shen, L.; Zheng, X.; Huang, R.; Yan, J.; Guo, H. TGF $\beta 1$ secreted by cancer-associated fibroblasts induces epithelial-mesenchymal transition of bladder cancer cells through lncRNA-ZEB2NAT. Sci. Rep. 2015, 5, 11924. [CrossRef]

88. Sun, Y.; Fan, X.; Zhang, Q.; Shi, X.; Xu, G.; Zou, C. Cancer-associated fibroblasts secrete FGF-1 to promote ovarian proliferation, migration, and invasion through the activation of FGF-1/FGFR4 signaling. Tumor Biol. 2017, 39. [CrossRef]

89. Santolla, M.F.; Vivacqua, A.; Lappano, R.; Rigiracciolo, D.C.; Cirillo, F.; Galli, G.R.; Talia, M.; Brunetti, G.; Miglietta, A.M.; Belfiore, A.; et al. GPER Mediates a Feedforward FGF2/FGFR1 Paracrine Activation Coupling CAFs to Cancer Cells toward Breast Tumor Progression. Cells 2019, 8, 223. [CrossRef]

90. Giulianelli, S.; Cerliani, J.P.; Lamb, C.A.; Fabris, V.T.; Bottino, M.C.; Gorostiaga, M.A.; Novaro, V.; Góngora, A.; Baldi, A.; Molinolo, A.; et al. Carcinoma-associated fibroblasts activate progesterone receptors and induce hormone independent mammary tumor growth: A role for the FGF-2/FGFR-2 axis. Int. J. Cancer 2008, 123, 2518-2531. [CrossRef]

91. Bai, Y.-P.; Shang, K.; Chen, H.; Ding, F.; Wang, Z.; Liang, C.; Xu, Y.; Sun, M.H.; Li, Y.Y. FGF-1/-3/FGFR4 signaling in cancer-associated fibroblasts promotes tumor progression in colon cancer through Erk and MMP-7. Cancer Sci. 2015, 106, 1278-1287. [CrossRef]

92. Knuchel, S.; Anderle, P.; Werfelli, P.; Diamantis, E.; Rüegg, C. Fibroblast surface-associated FGF-2 promotes contact-dependent colorectal cancer cell migration and invasion through FGFR-SRC signaling and integrin $\alpha v \beta 5-m e d i a t e d$ adhesion. Oncotarget 2015, 6, 14300-14317. [CrossRef]

93. Lo, A.K.-F.; Dawson, C.W.; Young, L.S.; Ko, C.-W.; Hau, P.-M.; Lo, K.-W. Activation of the FGFR1 signalling pathway by the Epstein-Barr virus-encoded LMP1 promotes aerobic glycolysis and transformation of human nasopharyngeal epithelial cells. J. Pathol. 2015, 237, 238-248. [CrossRef] [PubMed]

(C) 2019 by the author. Licensee MDPI, Basel, Switzerland. This article is an open access article distributed under the terms and conditions of the Creative Commons Attribution (CC BY) license (http://creativecommons.org/licenses/by/4.0/). 